Journal of Educational $\begin{aligned} & \text { Journal of Educational Chemistry (1 (1), Juni 2019, 44-50) } \\ & \text { Website: http://www.journal.walisongo.ac.id/index.php/jec } \\ & \text { ISSN 2685-4880 } \\ & \text { Chemistry }\end{aligned}$
DOI: $10.21580 /$ jec.2019.1.1.3936

\title{
Pengembangan Blog Pembelajaran Kimia Berbasis Contextual Teaching Learning (CTL) Materi Reaksi Oksidasi-Reduksi
}

\author{
Yeni Sulistyani $^{1^{*}}$ dan Ratih Rizqi Nirwana $^{2}$ \\ ${ }_{1}^{1} \mathrm{MA} \mathrm{Al} \mathrm{Hikmah} \mathrm{Pati}$ \\ ${ }^{2}$ Program Studi Pendidikan Kimia Fakultas Sains dan Teknologi Universitas Islam Negeri \\ Walisongo Semarang, Indonesia \\ *Email: ysulistyani04@gmail.com
}

\begin{abstract}
This research aims to develop blogs as a media which can expected to make it easier for students to access subject matter. The development of this learning blog is expected to improve students' understanding of the concept of reduction oxidation reactions. This study uses the Research and Development (RnD) development method, with the Reisser and Molenda models (1990s), namely the ADDIE model which includes analysis, design, development, implementation, and evaluation. Learning blogs that have been developed have a very high or very effective category based on student learning outcomes which include cognitive at $80.04 \%$, affective at 85.8\%, psychomotor at 84\%, and responses from students at 85.83\%. This learning blog is worthy of being used as a learning media to support chemistry learning using contextual teaching and learning in the material concept of oxidation-reduction reactions.
\end{abstract}

Keywords: Learning Blog, Contextual Teaching And Learning (CTL), Concept of Oxidation-Reduction Reaction

44

Copyright (C) 2019 JEC | ISSN 2685-4880

Volume 1, Nomor 1, Juni 2019 


\begin{abstract}
Abstrak
Pelaksanaan pembelajaran harus mampu menyesuaikan diri agar tujuan pendidikan dapat tercapai. Kegiatan pembelajaran peserta didik tidak hanya dapat dilakukan di sekolah dan pada jam pelajaran saja. Kemudahan akses internet seharusnya dapat dimanfaatkan peserta didik sebagai salah satu sumber belajar. Saat ini sudah tersedia banyak situs yang menampilkan materi-materi pelajaran, namun masih banyak informasi yang tidak sesuai. Sehingga diperlukan pengembangan secara optimal agar bahan ajar yang diakses siswa tepat. Penggunaan blog sebagai media diharapkan dapat memudahkan peserta didik untuk mengakses materi pelajaran. Materi konsep reaksi oksidasi reduksi merupakan salah satu materi yang dianggap sulit peserta didik. Pengembangan blog pembelajaran ini diharapkan mampu meningkatkan pemahaman peserta didik mengenai konsep reaksi oksidasi reduksi. Penelitian ini menggunakan metode pengembangan Research and Development ( $R \quad D$ ), dengan model Reisser dan Molenda (1990-an) yaitu model ADDIE yang meliputi analysis, design, development, implementation, dan evaluation. Blog pembelajaran yang telah dikembangkan mempunyai kategori sangat tinggi atau sangat efektif berdasarkan hasil belajar peserta didik yang meliputi kognitif sebesar 80,04\%, afektif sebesar 85,8 $\%$, psikomotorik sebesar 84\%, dan tanggapan peserta didik sebesar 85,83\%. Blog pembelajaran ini layak digunakan sebagai media pembelajaran penunjang pembelajaran kimia berbasis contextual teaching and learning pada materi konsep reaksi oksidasi-reduksi.
\end{abstract}

Kata kunci: Blog Pembelajaran, Contextual Teaching And Learning (CTL), Konsep Reaksi Oksidasi-Reduksi

\title{
Pendahuluan
}

Inti belajar adalah adanya perubahan tingkah laku, berupa perubahan ketrampilan, kebiasaan, sikap, pengetahuan, pemahaman, dan apresiasi karena adanya suatu pengalaman dalam proses belajar yang berupa interaksi antara peserta didik, pendidik dan lingkungan. Pembelajaran yang dilakukan oleh peserta didik tidak hanya dilakukan di sekolah, tetapi dilakukan di rumah dan lingkungan sekitar. Pembelajaran tidak harus dilakukan pada saat jam sekolah berlangsung, tetapi juga dapat dilakukan kapanpun dan di manapun tanpa batasan waktu, oleh karena itu belajar seharusnya tidak dibatasi oleh ruang dan waktu.

Teknologi komputer dan internet memberikan banyak tawaran dan pilihan bagi dunia pendidikan untuk menunjang proses pembelajaran (Sa`ud, 2009). Hal inilah yang seharusnya dimanfaatkan dan dikembangkan

secara optimal dalam proses belajar peserta didik. Banyak media internet yang menyuguhkan berbagai materi pembelajaran, tetapi terkadang materi yang disajikan kurang dapat dipertanggungjawabkan, sehingga sering membuat kesalahan informasi yang didapat oleh peserta didik. Materi pembelajaran yang ada di internet biasanya dipublikasikan melalui website ataupun weblog (blog). Blog merupakan media informasi yang memudahkan seseorang bertukar ilmu (Zakaria, 2009). Hal ini karena blog sangat fleksibel dalam penggunaannya karena dapat diakses kapanpun dan dimanapun (Fatmayanti, 2015)

Blog sebagai media pembelajaran akan dapat menarik perhatian dan mendorong motivasi belajar peserta didik. Media pembelajaran yang tepat akan memudahkan pemahaman peserta didik. Khususnya dalam memahami konsep- 
konsep materi kimia yang dianggap sulit dan abstrak oleh peserta didik. Salah satunya adalah materi konsep reaksi oksidasi-reduksi. Adanya blog pembelajaran ini peserta didik dapat secara langsung melihat bagaimana proses terjadinya reaksi oksidasi-reduksi dengan adanya video serta dapat mempermudah pemahaman peserta didik melalui materi yang disajikan. Dari penelitian yang telah dilakukan oleh Mukhlishin, dkk (2006), bahwa pengembangan blog sebagai media pembelajaran tergolong baik karena dapat meningkatkan pemahaman peserta didik. Selain itu, penelitian yang dilakukan oleh Baehaqi (2012) pemanfaatan media blog dapat meningkatkan hasil belajar peserta didik.

Pemahaman akan dirasa lebih optimal dan mempunyai nilai manfaat jika proses pembelajaran dikaitkan atau dihubungkan dengan dunia nyata peserta didik yang ada di kehidupan sekitar mereka yaitu melalui pendekatan Contextual Teaching and Learning (CTL). Menurut Nurhadi (2003: 4), pendekatan CTL adalah suatu konsep belajar di mana guru menghadirkan situasi dunia nyata ke dalam kelas dan mendorong siswa membuat hubungan antara pengetahuan yang dimilikinya dengan penerapannya dalam kehidupan siswa sebagai anggota keluarga dan masyarakat. Penelitian Sulastry dan Juniar (2011) tentang penerapan perangkat pembelajaran menunjukkan keefektifan yang cukup besar dengan menerapkan model pembelajaran CTL (Sulastry, Taty, Jusniar, 2011).

Kompetensi dasar dari materi reaksi oksidasi-reduksi adalah menjelaskan perkembangan konsep reaksi oksidasi reduksi dan hubungannnya dengan tatanama senyawa serta penerapannya maka pendekatan Contextual Teaching and Learning (CTL) melalui blog pembelajaran kimia dirasa tepat dalam penerapan konsep oksidasi-reduksi. Terkait dengan pengembangan blog berbasis Contextual Teaching and Learning (CTL), peneliti telah melakukan observasi dan wawancara dengan peserta didik dan guru di MA. Miftahul Huda Tayu-Pati. Informasi yang didapat adalah bahwa media blog belum pernah digunakan dalam proses pembelajaran kimia, hal ini tentunya akan menjadi hal baru dan menarik perhatian peserta didik tanpa mengesampingkan keutamaan pendidikannya dan pada materi konsep reaksi oksidasi-reduksi ini kurang dikaitkan dengan kehidupan sehari-hari peserta didik.

\section{Metode Penelitian}

Penelitian ini menggunakan metode penelitian dan pengembangan Research and Development $(R \& \mathrm{D})$. Model pengembangan yang dipilih dalam penelitian ini adalah model ADDIE yang dikembangkan oleh Reiser dan Mollenda dalam merancang sistem pembelajaran. Tahapan model ADDIE yaitu meliputi analysis, design, development, implementation, dan evaluation (Wegener, (2006).

Adapun tahapan prosedur pada penelitian pengembangan ini ada empat, yaitu studi pendahuluan, pengembangan prototipe, uji lapangan serta diseminasi dan sosialisasi.

\section{Studi pendahuluan}

Studi pendahuluan dalam proses ADDIE ini adalah tahapan analisis yang merupakan proses mendefinisikan apa yang akan dipelajari peserta didik. Tahap ini dilakukan dengan dua cara yaitu dalam bentuk survei lapangan yang meliputi analisis kinerja (performance analysis) dan analisis kebutuhan peserta didik serta studi kepustakaan. Pengembangan prototipe terdiri dari 4 tahapan, yaitu desain dan pengembangan yang di dalamnya mencakup validasi produk oleh ahli dan uji kualitas pada kelompom kecil (Suwahono, 2012).

\section{Uji lapangan}

Uji lapangan terdiri dari tahap implementasi dan tahap evaluasi. Implementasi produk pengembangan blog pembelajaran kimia berbasis Contextual Teaching and Learning 
dilakukan dengan 2 tahap uji lapangan yaitu pada kelas kecil dan kelas besar.

\section{Diseminasi}

Diseminasi merupakan langkah untuk menyosialisasikan dan menyebarluaskan hasil. Secara tidak langsung produk yang telah direvisi akan diseminasi (disebarluaskan) melalui situs blog pembelajaran kimia ini dan sudah dapat digunakan oleh guru ataupun peserta didik.

\section{Hasil Penelitian dan Pembahasan}

Penelitian dan pengembangan ini menghasilkan sebuah produk berupa blog pembelajaran kimia berbasis Contextual Teaching and Learning (CTL) pada materi konsep reaksi oksidasi-reduksi untuk membantu peserta didik dalam kemampuan scientific skill sehingga peserta didik akan lebih memahami materi serta ikut aktif dalam kegiatan pembelajaran. Berikut ini menu-menu pada blog antara lain:

1. Menu home yang merupakan beranda atau tampilan awal dari blog pembelajaran kimia.

2. Menu kurikulum yang berisi standar kompetensi, kompetensi dasar, tujuan pembelajaran.

3. Menu apersepsi yang berisi tentang pengenalan awal tentang konsep reaksi oksidasi-reduksi.

4. Menu materi pelajaran yang terdiri dari tiga materi, yaitu konsep oksidasi-reduksi berdasarkan pelepasan dan pengikatan oksigen, konsep oksidasi-reduksi berdasarkan pengikatan dan penerimaan elektron, konsep oksidasi-reduksi berdasarkan kenaikan dan penurunan bilangan oksidasi, pengoksidasi dan pereduksi.

5. Menu diskusi yang terdapat beberapa permasalahan yang berkaitan dengan peranan konsep reaksi oksidasi-reduksi dalam kehidupan sehari-hari.

6. Menu percobaan yang berisi video percobaan yang dilengkapi dengan lembar kerja peserta didik.
7. Menu refleksi yaitu sebagai pencerminan pengetahuan peserta didik setelah menerima materi di akhir pembelajaran.

8. Menu penilaian yang terdiri dari 2 tugas yaitu tugas yang berisi soal-soal evaluasi (isian) dan tugas portofolio (membuat artikel tentang peranan konsep reaksi oksidasireduksi dalam kehidupan sehari-hari).

Uji efektifitas pada tahap penelitian dan pengembangan ini telah melibatkan peserta didik kelas X yang berjumlah 25 peserta didik dan pendidik kimia kelas X. Berikut ini adalah hasil uji efektifitas blog kimia yang peneliti kembangkan:

1. Aspek kognitif

Tabel 1. Persentase Pre-test dan Post-test

\begin{tabular}{lllll}
\hline $\begin{array}{l}\text { Rerata } \\
\text { pre- } \\
\text { test }\end{array}$ & $\begin{array}{l}\text { Rerata } \\
\text { Post- } \\
\text { test }\end{array}$ & $\begin{array}{l}\text { Jumlah } \\
\text { Peserta } \\
\text { Didik yang } \\
\text { Tuntas }\end{array}$ & $\begin{array}{l}\text { Kelulusan } \\
\text { Klasikal }\end{array}$ & Kriteria \\
\hline 56,16 & 80,04 & 25 & $100 \%$ & $\begin{array}{l}\text { Sangat } \\
\text { Tinggi }\end{array}$ \\
\hline
\end{tabular}

2. Aspek Afektif

Tabel 2. Hasil Persentase Aspek Afektif Peserta Didik pada Pembelajaran I dan II

\begin{tabular}{llll}
\hline Indikator & $\begin{array}{l}\text { Pembel } \\
\text { ajaran I I }\end{array}$ & $\begin{array}{l}\text { Pembel } \\
\text { ajaran } \\
\text { II }\end{array}$ & Rata-rata \\
\hline Menerima & $82 \%$ & $92 \%$ & $87 \%$ \\
Menanggapi & $80 \%$ & $91 \%$ & $85,5 \%$ \\
Menilai & $80 \%$ & $91 \%$ & $85,5 \%$ \\
Mengorganisasi & $79 \%$ & $93 \%$ & $86 \%$ \\
Rata-rata & $80,4 \%$ & $91,2 \%$ & $85,8 \%$ \\
\hline
\end{tabular}

3. Aspek Psikomotorik

Tabel 3. Hasil Aspek Psikomotorik Peserta Didik

\begin{tabular}{lll}
\hline Indikator & & Persentase \\
\hline $\begin{array}{l}\text { Melakukan } \\
\text { guru }\end{array}$ & tugas & dari instruksi $85 \%$ \\
Mengamati dan mencatat hasil $93 \%$
\end{tabular}


percobaan

Menyajikan

dan $73 \%$

mempresentasikan hasil praktikum

Rata-rata

$84 \%$

4. Tanggapan Peserta Didik Terhadap Blog Pembelajaran Kimia Berbasis CTL

Tabel 4. Hasil Angket Tanggapan Peserta Didik di Kelas

\begin{tabular}{lll}
\hline Indikator & $\begin{array}{l}\text { Rata-rata } \\
\text { Persentase }\end{array}$ & Kriteria \\
\hline Kualitas Isi & $85,4 \%$ & Efektif \\
Rasa Senang & $85,6 \%$ & Efektif \\
Evaluasi & $85,2 \%$ & Efektif \\
Motivasi & $87,2 \%$ & Sangat \\
& & Efektif \\
Tata Bahasa & $86 \%$ & Sangat \\
& & Efektif \\
Tampilan & $86 \%$ & Efektif \\
Tingkat & $85,8 \%$ & Efektif \\
Pencapaian & & \\
\hline
\end{tabular}

Pengembangan dan penelitian ini menghasilkan produk yang berupa blog pembelajaran kimia berbasis Contextual Teaching and Learning (CTL) pada materi konsep reaksi oksidasi-reduksi. Media pembelajaran blog ini didesain menggunakan model pengembangan Reiser dan Mollenda yaitu ADDIE yang terdiri dari analysis, design, development, implementation, dan evaluation. Blog yang dikembangkan menggunakan Blogger.com atau Blogspot, selanjutnya untuk gambar bersumber dari Google dan video

48

Copyright (C) 2019 JEC | ISSN 2685-4880

Volume 1, Nomor 1, Juni 2019

bersumber dari Youtube, sedangkan penulisan rumus kimia menggunakan www.codecogs.com/latex/eqneditor.php yang hasilnya berupa gambar dan bisa di salin ke entri saat membuat blog. Hasil blog pembelajaran kimia berbasis Contextual Teaching and Learning (CTL) pada materi konsep reaksi oksidasi-reduksi bisa langsung mengunjungi alamat www.sekolahkimia.blogspot.co.id. Adapun yang terdapat pada blog pembelajaran ini antara lain:

1. Materi konsep reaksi oksidasi reduksi yang dibahas adalah mengenai perkembangan dan konsep reaksi oksidasi-reduksi serta peranannya dalam kehidupan sehari-hari.

2. Setiap perpindahan subbab pada materi disediakan contoh reaksi yang terjadi di kehidupan sehari-hari.

3. Karakteristik blog ini adalah blog kimia yang berbasis Contextual Teaching and Learning (CTL), dimana peserta didik secara nyata dapat mengetahui peranan dari materi (konsep oksidasi-reduksi) sehingga membantu peserta didik dalam memahami materi tersebut.

Uji keefektifan blog pembelajaran kimia berbasis Contextual Teaching and Learning (CTL) dengan memberikan pres-test dan posttest untuk mengetahui hasil belajar peserta didik kimia di kelas besar dan adanya observasi langsung untuk mengetahui keaktifan peserta didik saat proses pembelajaran menggunakan blog pembelajaran kimia berbasis Contextual Teaching and Learning (CTL) serta uji kelayakan blog pembelajaran berupa angket tanggapan untuk peserta didik di kelas besar. Uji coba kelas besar dapat disimpulkan bahwa blog pembelajaran kimia berbasis Contextual Teaching and Learning (CTL) materi konsep reaksi oksidasi-reduksi sangat efektif diterapkan pada pembelajaran kelas besar, hal ini ditunjukkan dengan tercapainya indikator keefektifan yang ada. 
Hasil belajar peserta didik di kelas besar mengalami peningkatan dengan tingkat kelulusan klasikal peserta didik mencapai 100\% dengan jumlah peserta didik yang memperoleh nilai post-test $>65 \%$ ialah 25 peserta didik, sehingga semua peserta didik dapat dikatakan lulus. Adapun persentase nilai pre-test pada hasil uji lapangan luas atau kelas besar adalah56,16\%, sedang persentase nilai post-test peserta didik pada uji lapangan luas atau kelas besar adalah 80,04\%. Peningkatan skor hasil belajar peserta didik pada hasil uji coba kelas besar. Berdasarkan hasil evaluasi aspek kognitif kelas besar dapat dinyatakan bahwa blog pembelajaran kimia berbasis Contextual Teaching and Learning (CTL) pada materi konsep reaksi oksidasi-reduksi sangat efektif digunakan dalam kegiatan pembelajaran.

Indikator ketercapaian dari aspek afektif pada kelas besar menunjukkan perbedaan nilai persentase pada masing-masing indikator. Persentase tertinggi terdapat pada indikator menerima yaitu sebanyak $87 \%$, artinya sebagian besar peserta didik mengikuti, mencermati dan antusias terhadap kegiatan pembelajaran yang berlangsung dengan sangat baik. Indikator mengorganisasi sebanyak 86\%, ini berarti 86\% peserta didik mampu melaksanakan tugas yang diberikan pendidik dengan sangat tepat. Indikator menanggapi dan menilai mendapatkan persentase yang sama yaitu sebanyak $85,5 \%$, hal ini menunjukkan bahwa sebanyak $85,5 \%$ peserta didik sangat aktif saat pembelajaran dengan menjawab serta mengajukan beberapa pertanyaan saat pembelajaran berlangsung dan mampu menjelaskan dan mengkomunikasikan ke peserta didik lain.

Presentase pada masing-masing indikator ranah aspek psikomotorik di kelas kecil dengan menggunakan blog pembelajaran kimia sebanyak $85 \%$ pada indikator melakukan tugas dari instruksi guru, ini berarti bahwa peserta didik sangat baik dalam melakukan tugas yang diberikan oleh guru. Indikator mengamati dan mencatat hasil percobaan memperoleh persentase sebanyak 93\%, hal ini menunjukkan bahwa peserta didik sangat baik dalam mengamati dan mencatat hasil percobaan yang diperoleh dari menonton video percobaan. Indikator menyajikan dan mempresentasikan hasil praktikum memperoleh persentase sebanyak $73 \%$, artinya peserta didik secara baik dapat menjelaskan di depan kelas tentang hasil percobaan yang didapat melalui video percobaan. Kesimpulannya bahwa pembelajaran dengan menggunakan blog pembelajaran mendapatkan hasil kriteria sangat efektif.

Angket uji kelayakan media pembelajaran pada uji lapangan kelas besar dengan pemberian angket tanggapan media kepada peserta didik kelas besar mendapatkan kriteria sangat efektif dengan tingkat pencapaian 85,9\%. Berdasarkan paparan indikator pencapaian keefektifan media yang diperoleh, diketahui bahwa blog pembelajaran kimia berbasis Contextual Teaching and Learning (CTL) pada materi konsep reaksi oksidasi-reduksi sangat efektif dan layak digunakan dalam proses pembelajaran kimia pada materi konsep reaksi oksidasi-reduksi. Hal ini dikarenakan media pembelajaran yang dikembangkan mudah untuk dipelajari, bersifat mandiri dan mendukung pembelajaran di kelas maupun di luar kelas.

\section{Kesimpulan}

Blog pembelajaran kimia berbasis Contextual and Teaching Learning (CTL) pada materi konsep reaksi oksidasi-reduksi yang dikembangkan ini terbukti efektif digunakan dalam proses pembelajaran.

\section{Daftar Pustaka}

Baehaqi, I. (2012). Pemanfaatan Media Blog pada Pembelajaran Kimia Materi Hidrokarbon dan Minyak Bumi untuk Meningkatkan Hasil Belajar Peserta didik Kelas Xa MA NU Nurul Huda Semarang. Skripsi. Semarang: Fakultas Ilmu Tarbiyah dan Keguruan IAIN Walisongo Semarang. 
Fatmayanti, A. (2015). Pengembangan Media Blog Sebagai Sarana Informasi Untuk Meningkatkan Kemampuan Perencanaan Karir Di SMAN 1 Bulukumba. Jurnal Psikologi Pendidikan Dan Konseling. 1(2): 163-169.

Hakim, F. (2015). Pengembangan Modul Kimia Terintegrasi Karakter Islami Pada Materi Reaksi Redoks di MAN 1 Kudus. Journal of Innovative Science Education. Vol 4 No 1.

Mukhlishin, Hamdil, dkk. (2006). Pengembangan Blog Sebagai Media Pembelajaran Untuk Perolehan Belajar Konsep Kimia Karbon Di Universitas Muhammadiyah Pontianak. Pontianak: FKIP Universitas Tanjungpura, hlm. 11-12.

Nurhadi, A. G. S. (2003). Pembelajaran Kontekstual dan Penerapannya dalam KBK. Malang: Universitas Negeri Malang.

Sa'ud, Udin Syaefudin. (2009). Inovasi Pendidikan. Alfa Beta: Bandung.

Sulastry, Taty, \& Jusniar. (2011). Pengembangan Perangkat Pembelajaran Kimia Berbasis Contekstual Teaching And Learning pada Materi Pokok Laju Reaksi, Malang: UNM, Jurnal Chemica Vol.12 No.2 hlm. 59-68.

Suwahono. (2012). Pengembangan Sistem Penilaian Keterampilan Generic Kimia

Wegener, D. R. (2006). Training Library Patrons the ADDIE Way, Oxford: Chandos Publishing.

Zakaria, R. (2009). Ayo! Membuat Blog Multimedia, Yogyakarta: A'Plus Book, hlm 14. 